\title{
CRIBELLOPSIS MOULLADEI (SAINT-MARC, 1974) NOV. COMB. (FORAMINIFERIDA, ORBITOLINIDAE): AN ALBIAN MARKER TAXON OF THE SOUTHERN NEOTETHYSIAN MARGIN
}

\author{
Felix Schlagintweit
}

Received: 7 October 2019 / Accepted: 1 November 2019 / Published online: 5 November 2019

\begin{abstract}
The species Simplorbitolina moulladei described by Saint-Marc, 1974 from the middle Albian of Lebanon is taxonomically revised and assigned to the genus Cribellopsis Arnaud-Vanneau, 1980. Both, Paracoskinolina prestati Delmas \& Peybernès, 1981 (middle-upper Albian of Somalia) and Cribellopsis arnaudae Chiocchini, 1989 (Albian of Italy) are considered as subjective junior synonyms. Cribellopsis moulladei is regarded a taxon restricted to the southern (here: "African") Neotethysian margin. All other representatives of the genus Cribellopsis were reported from the northern Neotethysian margin.
\end{abstract}

Keywords: Foraminifera, Lower Cretaceous, Systematics, Biostratigraphy, Palaeogeography

\section{INTRODUCTION}

Saint-Marc (1974) described a new Orbitolinidae as Simplorbitolina moulladei from the middle Albian of Lebanon, respectively a section named Dlebta-Chenan Aaïr, located about $12 \mathrm{~km}$ north-east of Beirut. It was illustrated by six sections (three axial and three transverse). $S$. moulladei represents a poorly known taxon and has not been illustrated in the literature since then. It has been validly described (holotype designation etc.), but its taxonomy needs revision. The marginal zone of $S$. moulladei species lacks rafters (= horizontal partitions), possesses beams and up to three intercalary beams. The rather wide central part of the test consists of a poorly defined reticular zone, formed by anastomosing short radial partitions (beams) which alternate in position between subsequent chambers (Saint-Marc, 1974, p. 226 "structure partiellement réticulaire"). In Simplorbitolina Ciry \& Rat, 1953 instead the primary partitions are rather long (almost reaching the centre of the test), meandriform, forming a radial zone (see Hottinger, 2006), followed by a distinctly reduced reticulate central part (ArnaudVanneau, 1980, fig. 218; Schroeder, 1985). The taxonomic revision provided in the present paper results in the assignment of the species Simplorbitolina moulladei to the genus Cribellopsis Arnaud-Vanneau, 1980.

\section{SYSTEMATICS}

Phylum Foraminifera d'Orbigny, 1826

Class Globothalamea Pawlowski et al., 2013

Order Loftusiida Kaminski \& Mikhalevich in Kaminski, 2004

Suborder Orbitolinina Kaminski, 2004

Superfamily Orbitolinoidea Martin, 1890

Family Orbitolinidae Martin, 1980

Subfamily Dictyoconinae Moullade, 1965

Genus Cribellopsis Arnaud-Vanneau, 1980

Type-species: Orbitolinopsis neoelongata Cherchi \& Schroeder, 1978
Remarks: The genus Cribellopsis is characterized by a simple (= without partitions), often bilocular (= protoconch and deuteroconch) embryo located slightly eccentric near the apex or at the beginning of a small spire, a marginal zone subdivided by vertical partitions (beams, Hottinger, 2006), often with several orders, and a rather wide central reticulate zone. Horizontal partitions (rafters) are absent in the species described so far. Foramina show an oblique and vertical arrangement (ArnaudVanneau, 1980; Chiocchini, 1989; Clavel in Granier et al., 2013). Cribellopsis represents a rather simply structured orbitolinid whose species are classically differentiated above all by dimensional and morphological criteria.

Cribellopsis moulladei (Saint-Marc, 1974) comb. nov.

Fig. 1a-s

1974 Simplorbitolina moulladei n. sp. - Saint-Marc, p. 225, pl. 2, figs. 3-8.

1977 Coskinolina sunnilandensis Maync - Prestat, pl. 12, figs. 1-2.

1977 Coskinolina sp. - Prestat, pl. 12, figs. 3-7, 14-17.

1977 Iraqia sp. - Prestat, pl. 12, figs. 8-10 (B-forms).

1981 Paracoskinolina prestati n. sp. - Peybernès and Delmas, 81, figs. 1-7.

1982 Paracoskinolina prestati nom. nud. - Peybernès, pl. 2, figs. 9-12.

1989 Cribellopsis arnaudae n. sp. - Chiocchini. p. 42, pls. 1-2.

2012 Cribellopsis arnaudae Chiocchini - Chiocchini et al., pl. 69, fig. 1 pars, figs. 2-10.

2018 Cribellopsis aff. arnaudae Chiocchini - Cruz Abad, p. 111, figs. 92-93.

2019 in press Cribellopsis arnaudae Chiocchini Schmitt et al., fig. 5D.

Descriptions: Test finely agglutinating, medium- to high conical. The cone base is almost flat in juvenile specimens, becoming convex in adult forms. Large sized, 


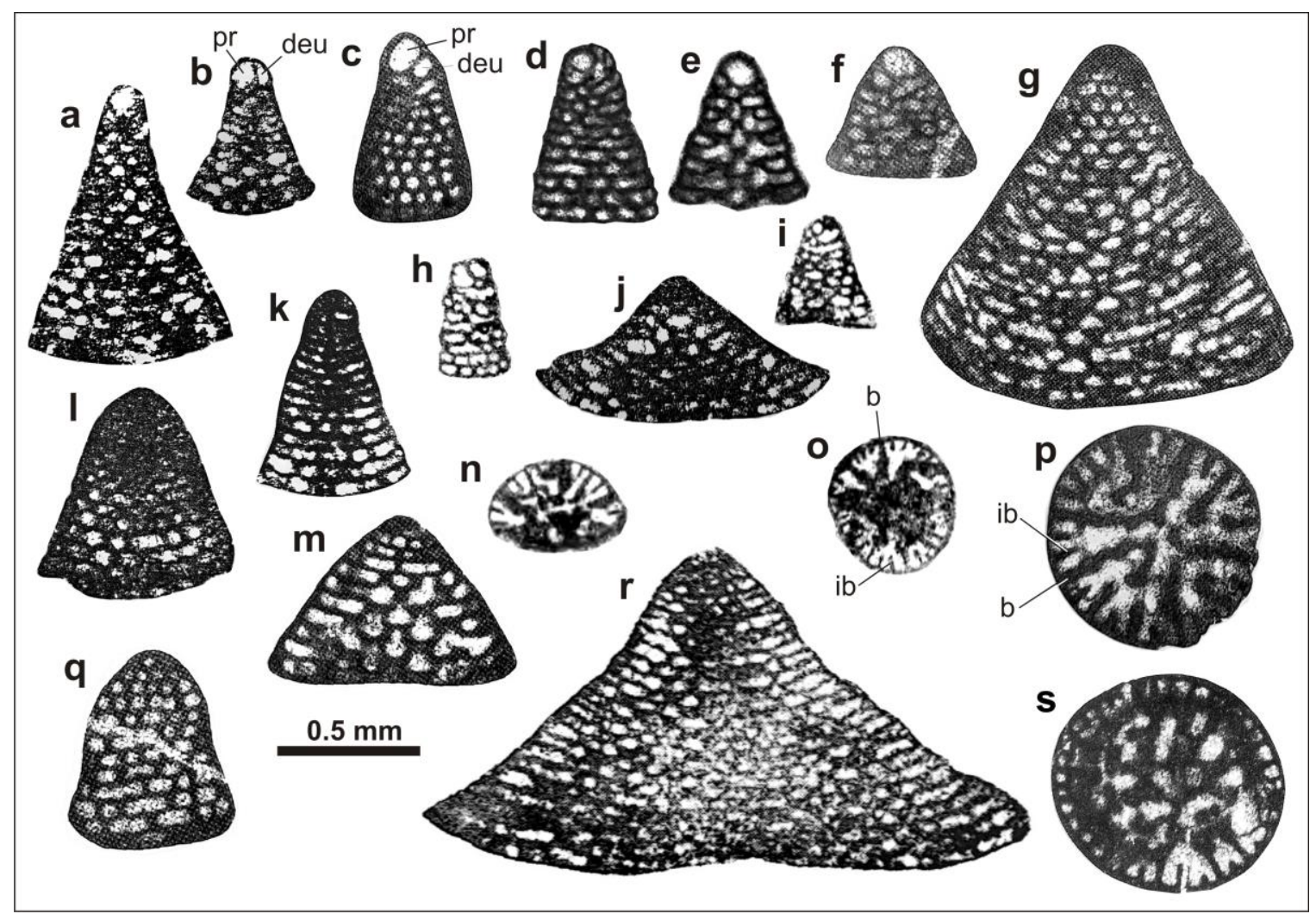

Fig. 1 Cribellopsis moulladei (Saint-Marc) nov. comb., Albian of Somalia (a-b, j-l, r), Italy (c--g, m, p-q, s), and Lebanon (h-i, $\mathbf{n}-\mathbf{0}$; type material). a-f Axial sections of megalospheric specimens. $\mathbf{g}, \mathbf{r}$ Subaxial sections of possibly microspheric specimens. $\mathbf{h}-\mathbf{i}, \mathbf{k}$ Subaxial sections of megalospheric specimens. $\mathbf{j}, \mathbf{m}$ Tangential-oblique sections. l, q Tangential sections. n-p, s Transverse sections. a-b, k extracted from Peybernès \& Delmas (1981, pl. 1, fig. 1-2, h ) as Paracoskinolina prestati; j, l extracted from Peybernès (1982, pl. 2, fig. 12, fig. 11) illustrated as Paracoskinolina prestati; $\mathbf{c}, \mathbf{f}-\mathbf{g}, \mathbf{m}, \mathbf{p}, \mathbf{q}, \mathbf{s}$ extracted from Chiocchini (1989, pl. 1, fig. 14, fig. 5, pl. 2, fig. 8, pl. 1, fig. 11, fig. 10, fig. 12, fig. 4) illustrated as Cribellopsis arnaudae n. sp.; d extracted from Schmitt et al. (2019, in press, fig. 5d) illustrated as Cribellopsis arnaudae Chiocchini. e extracted from Cruz-Abad (2018, fig. 93J) illustrated as Cribellopsis aff. arnaudae Chiocchini; h-i, n-o extracted from Saint-Marc (1974, pl. 2, figs. 6, 3-4, 7) illustrated as Simplorbitolina moulladei n. sp. r extracted from Prestat (1977, pl. 12, fig. 10) illustrated as Iraqia sp. Abbreviations: b = beam (or main partition), deu $=$ deuteroconch, $\mathrm{ib}=$ intercalary beam, $\mathrm{pr}=$ proloculus

medium-conical specimens, which may show a slight depression in the central part of the base are interpreted as microspheric forms (Fig. 1j, r). The megalospheric embryo is situated at the rounded apex or positioned slightly eccentrically (Fig. 1a-f, ?h). Sometimes a twochambered simple (= no partitions) embryo consisting of a subspherical protoconch and a smaller hemispherical deuteroconch is observable (Fig. $1 \mathrm{~b}-\mathrm{c}$, ?h). There are up to $\sim 25$ uniserial chambers in adult specimens. The welldeveloped marginal zone is subdivided by two orders of beams, primary beams and up to 3 short intercalary beams (Fig. 1o-p, s). The primary beams are either straight or slightly undulating. Inwards they fuse laterally thereby forming a loose central network (Fig. 1n, p, s). In axial sections, they display an alternating position between subsequent chambers and a tendency to thicken in direction to the apex resulting in a triangular shape. In shallow tangential sections the beams exhibit an alternating rectangular pattern (Fig. 1c, h, 1, q). The foramina distributed in the central zone are predominantly arranged oblique but may be also vertical.

Dimensions: see Table 1 for Cribellopsis moulladei (Saint-Marc) nov. comb., compared to proposed syno- nyms. Further comments are provided in the subchapter "Comparisons".

Comparisons: The following comparisons and remarks essentially refer to the proposed synonymy with the species Paracoskinolina prestati, Cribellopsis arnaudae, and a form recently described by Cruz-Abad (2018) as Cribellopsis aff. arnaudae. It is worth mentioning that all the mentioned taxa do not show any structural differences and cannot satisfactorily be separated biometrically (Table 1; and further comments in the text). For "Simplorbitolina" moulladei, no section displaying the embryo was provided. Saint-Marc (1974) just noted an initial spire of 3 to 4 chambers, but a simple (= non-septulate) bilocular embryo (protoconch + deuteroconch) is barely recognizable in the specimen illustrated in his plate 2, figure 6 (reillustrated in Fig. 1h). A slightly eccentric biloculine embryo is reported from both "Paracoskinolina" prestati (see Fig. 1b), and Cribellopsis arnaudae (Fig. 1c). The differences of the mentioned taxa refer to the dimensional data as indicated in the original works. 
Table 1 Biometrical parameters of Cribellopsis moulladei (Saint-Marc, 1974) nov. comb. and its assumed junior synonyms Paracoskinolina prestati Peybernès \& Delmas, 1981, Cribellopsis arnaudae Chiocchini, 1989 and Cribellopsis aff. arnaudae Chiocchini (see Cruz-Abad, 2018). a.a. = apical angle; $\mathrm{H}=$ test height; $\mathrm{D}=$ test diameter; $\mathrm{n}=$ number of chambers last $0.5 \mathrm{~mm}$ of the test; $*$ measured from the original illustrations; ? uncertainty due to poor quality of illustration.

\begin{tabular}{|c|c|c|c|c|c|c|c|}
\hline Species & a.a. & $\begin{array}{l}\mathbf{H} \\
(\mathbf{m m})\end{array}$ & $\begin{array}{l}\text { D } \\
(\mathbf{m m})\end{array}$ & H/D & $\begin{array}{l}\text { chamber } \\
\text { height } \\
(\mu \mathrm{m})\end{array}$ & $\mathbf{n}$ & $\begin{array}{l}\text { Diameter } \\
\text { proloculus } \\
(\mathrm{mm})\end{array}$ \\
\hline $\begin{array}{l}\text { Simplorbitolina moul- } \\
\text { ladei Saint-Marc, } 1975\end{array}$ & $30-50 *$ & $\operatorname{up}_{0.55}$ to & $\operatorname{up}_{0.53}$ to & $1.0-1.63$ & $40 *-50$ & - & - \\
\hline $\begin{array}{l}\text { Paracoskinolina presta- } \\
t i \text { Peybernès \& Del- } \\
\text { mas, } 1981\end{array}$ & $\begin{array}{l}40-50 * \\
(\mathrm{~A}- \\
\text { form) } \\
\sim 90(\mathrm{~B}- \\
\text { form) }\end{array}$ & $\operatorname{up}_{0.86}$ to & $\begin{array}{l}0.45- \\
0.61\end{array}$ & $1.0-1.5$ & $45 * ?$ & $11 * ?$ & $\sim 0.05-0.1 * ?$ \\
\hline $\begin{array}{l}\text { Cribellopsis arnaudae } \\
\text { Chiocchini, } 1988\end{array}$ & $40 *-65$ & $\begin{array}{ll}0.45 & *_{-} \\
1.290 & \end{array}$ & $\begin{array}{ll}0.45 & *_{-} \\
1.275 & \end{array}$ & $\begin{array}{l}\sim 1 \text { or } \\
\text { slightly } \\
\text { higher }\end{array}$ & $\begin{array}{l}65-85 \\
(40-50 \text { ?B- } \\
\text { forms })\end{array}$ & $7-10$ & $\sim 0.09-0.095$ \\
\hline $\begin{array}{l}\text { Cribellopsis. aff. ar- } \\
\text { naudae Chiocchini } \\
\text { sensu Cruz (2018) }\end{array}$ & $30-45$ & $\begin{array}{l}\text { up to } 1.7 \\
\text { mostly } \\
0.8-1.0\end{array}$ & $\begin{array}{l}\text { up to } 1.1 \\
\text { mostly } \\
0.5-0.7\end{array}$ & $1.1-1.7$ & $40-60$ & $6-9$ & - \\
\hline
\end{tabular}

\section{Paracoskinolina prestati Peybernés \& Delmas, 1981}

The axial sections provided by Peybernès and Delmas (1981) as well as those from Prestat (1977; see synonymy) clearly evidence that the "pillars" are not aligned between subsequent chambers (Fig. 1a-b, j-1, r). This feature, however, is one of the diagnostic characteristics of the genus Paracoskinolina Moullade (see ArnaudVanneau, 1980, or Clavel in Granier et al., 2013, p. 153). Therefore, the upper? Albian Somali taxon can not be a species of Paracoskinolina. In fact, the partitions of the central zone in Cribellopsis are thickening "upwards" (= towards the apex; Arnaud-Vanneau, 1980, p. 668, "épaississent vers le haut"). This feature observable in axial sections, was also reported by Saint-Marc (1974, p. 225) for "Simplorbitolina" moulladei ("cloisons radiales ont une section triangulaire, en cône renversé"). It is worth mentioning here that this aspect of the central zone is described from several doubtful paracoskinolinas such as $P$. tunesiana Peybernès, $P$. pfenderae Canérot \& Moullade, $P$. hispanica Peybernès, or $P$. querolensis Canérot $\&$ Peybernès as "hemi-pillars...pointe en haut" (e.g., Peybrnès and Delmas, 1981, p. 82). Transverse sections of Cribellopsis show that the vertical elements of the central zone are not isolated columnar pillars but sections of a reticulate (or anastomosing), often loose and poorly constrained, network formed by laterally fused main partitions (e.g., Fig. 1s). This statement does not mean per se that all of the above cited species belong to Cribellopsis. Their taxonomic status must be clarified individually.

\section{Cribellopsis arnaudae Chiocchini, 1989}

The Somali species Cribellopsis prestati possess striking similarities (e.g., rather voluminous embryo at the apex or slightly eccentric, bilocular with deuteroconch, equivalent exoskeleton, central zone with poor tendency to form an anastomosing reticulum, first and second order vertical partitions) with a taxon described by Chiocchini (1989) as Cribellopsis arnaudae from the upper Albian of southern Italy (see Chiocchini et al., 2012, fig. 9) (Fig. 1c, f-g, $\mathrm{m}, \mathrm{p}, \mathrm{q}, \mathrm{s})$. For both $P$. prestati and $C$. arnaudae, the original descriptions indicate (among others) as distinguishing criteria the comparably large-sized (sub)apical bilocular embryo and the ratio test height/diameter commonly around 1 (Peybernès and Delmas, 1981, p. 82; Chiocchini 1989, p. 46). Although Peybernés and Delmas (1981, p. 82) had only poorly preserved transverse sections at hand, they noted the presence of three intercalary beams ("trois cloisons secondaires"). The only differences seem to be a higher apical angle (see comments below for $C$. aff. arnaudae of Cruz-Abad 2018) and smaller dimensions in $C$. prestati, as indicated in the original descriptions (see comments below) (see Table 1). The differences can partly be explained by the exclusion of large-sized (presumably B-forms) of $C$. prestati on the one hand, combined with exclusion of juvenile specimens of $C$. arnaudae on the other hand. Prestat (1977, pl. 12, fig. 10) illustrated from the same level a large-sized low-conical orbitolinid of visibly identical internal structure as Iraqia sp. This specimen, here interpreted as a microspheric specimen, was not included in the species concept of $P$. prestati by Peybernès and Delmas (1981), and is here re-illustrated in Fig. 1r. Chiocchini (1989, pl. 2, figs. 2, 6, 15), on the other side, illustrated specimens of $C$. arnaudae with test diameter $<0.4 \mathrm{~mm}$, but the lowest value for the corresponding range was indicated as $0.685 \mathrm{~mm}$. With maximum test height of $0.55 \mathrm{~mm}$ (Saint-Marc, 1974), the Lebanese specimens obviously belong to small-sized juvenile forms. Another example is the number of chambers in adult specimens indicated as "12 to 18 " by Chiocchini (1989). The two large specimens shown in Chiocchini (1989, pl. 2, figs. 1 and 8), display about 25 chambers (almost the double maximum size as indicated). Summarizing, this means principally, that biometric data and respectively comparison tables included in original 
Table 2 Palaeogeographic distribution of species of Cribellopsis Arnaud-Vanneau along the two opposite margins of the Neotethysian Ocean (for further details on the species see Arnaud-Vanneau, 1980).

\begin{tabular}{|l|l|l|}
\hline Species of Cribellopsis & $\begin{array}{c}\text { Northern } \\
\text { Neoetethysian margin }\end{array}$ & $\begin{array}{c}\text { Southern } \\
\text { Neotethysian margin }\end{array}$ \\
\hline C. moulladei (Saint-Marc) & - & $\mathbf{X}$ \\
\hline C. elongata (Dieni, Massari \& Moullade) & $\mathbf{X}$ & - \\
\cline { 1 - 1 } C. neoelongata (Cherchi \& Schroeder) & $\mathbf{X}$ & - \\
\cline { 1 - 2 } C. schroederi Arnaud-Vanneau & $\mathbf{X}$ & - \\
\hline C. thieuloyi Arnaud-Vanneau & $\mathbf{X}$ & - \\
\hline
\end{tabular}

descriptions must be carefully checked, in cases be remeasured, and interpreted by subsequent workers (e.g., exclusion/inclusion/mixing of juvenile, adult specimens, A- and B-forms).

\section{Cribellopsis aff. arnaudae Chiocchini (Cruz-Abad, 2018)}

Last but not least, Cribellopsis aff. arnaudae Chiocchini has recently been reported from the upper Albian of southern Italy by Cruz (2018) differing from $C$. arnaudae by a more acute apical angle and a higher number of chambers in the last $0.5 \mathrm{~mm}$ test length. In any case, the higher apical angle fits within the range observed in " $P$ ". prestati. The differences are here interpreted as environmentally driven rather than being of taxonomic importance (= separate species). It is worth mentioning, that in juvenile specimens the apical angle is mostly higher whereas in adult stages there is a tendency for test widening (Schroeder, 1962, p. 174). In conclusion, also the forms described as Cribellopsis aff. arnaudae Chiocchini by Cruz-Abad (2018) are considered as subjective synonyms of Cribellopsis moulladei as interpreted herein.

Stratigraphy: Peybernès and Delmas (1981) described Paracoskinolina prestati from the upper? Albian Mustahil Formation of Somalia based on material from Prestat (1977) (see synonymy). It is worth mentioning that the top of the Mustahil Formation is considered an earlymiddle Albian age by Russo et al. (1991). There are contrasting views about the stratigraphic distribution of Cribellopsis arnaudae from Italy. In the original description C. arnaudae was considered a good marker species for lower Albian inner platform carbonate facies (Chiocchini, 1989, p. 40). Later, in a new stratigraphic compilation, $C$. arnaudae was assigned a short interval within the lowermost upper Albian (Chiocchini et al., 2012, fig. 9). In a recent contribution by Schmitt et al. (2019, in press), $C$. arnaudae was reported from the lower Albian based on Strontium isotope stratigraphy (and biostratigraphic data). Taking into account these contrasting views, it appears pragmatic, for the moment being, to consider $C$. moulladei an Albian marker taxon.

Palaeobiogeography: $C$. moulladei (Saint-Marc) and the proposed junior synonyms Paracoskinolina prestati and Cribellopsis arnaudae have so far not been reported from the northern Neotethysian margin. Lebanon, southern Italy and Somalia were belonging to the southern Neotethysian margin (e.g., Dercourt et al., 1993). With respect to the Northern Neotethysian margin, there were more endemic taxa of Lower Cretaceous Orbitolinidae (Cherchi et al. 1981; Arnaud-Vanneau 2006) (Table 2). C. neoelongata (Cherchi \& Schroeder, 1978), C. elongata (Dieni et al., 1963), C. thieuloyi Arnaud-Vanneau, 1980 and $C$. schroederi Arnaud-Vanneau, 1980 are all only known from areas formerly belonging to the northern Neotethysian margin in the upper Hauterivian-lower Aptian period (Clavel in Granier et al., 2013).

\section{ACKNOWLEDGEMENTS}

Thanks to Katharina Schmitt and Stephan Huck (both Hannover) for providing the photograph shown here in Figure 1d from the lower Albian of Italy. Many thanks to the reviewers Lorenzo Consorti (Trieste) and Mariano Parente (Naples) for providing helpful comments, and to François Le Coze (Saint-Etienne) for fruitful discussion.

\section{REFERENCES}

Arnaud-Vanneau, A., 1980. L’Urgonien du Vercors septentrional et de la Chartreuse. Géologie Alpine Mémoire, 11 (3 volumes): 1-874.

Arnaud-Vanneau, A., 2006. Biogeographic distribution of large shallow-water benthic foraminifers during the Early Cretaceous. Anuário do Instituto de Geociências 29 (1) (Forams 2006): p. 694.

Cherchi, A., Durand-Delga, M., Schroeder, R., 1981. Aperçu paléogéographique sur les Provinces à grands Foramninifères du Crétacé Inférieur dans le Cadre structural Méditerranéen. Rapport Commission Internationale Mer Méditerranée, 27: 115-119.

Cherchi, A., Schroeder, R., 1978. Osservazioni sul gen. Orbitolinopsis Silvestri (Foraminiferida) e sua presenza nel Barremiano della Sardegna. Bollettino della Società Sarda di Scienze Naturali, Anno XI, 17: 159167

Chiocchini, M., 1989. Cribellopsis arnaudae n. sp. (Foraminiferida, Orbitolinidae) nel Cretaceo inferior del Lazio meridionale e dell' Abruzzo (Italia central). Bolletino della Società Paleontologica Italiana, 28 (1): 39-48.

Chiocchini, M., Pampaloni, L., Pichezzi, R. M., 2012. Microfacies e microfossili delle successioni carbonatiche mesozoiche Lazio e Abruzzo. Memorie per Servire alla descrizione della Carta Geologica d'Italia, 17,223 plates.

Cruz-Abad, E., 2018. Textura y Arquitectura de los Orbitolinoideos (Superfamilia Orbitolinoidea): Revisión y Caracterización. PhD Thesis University of Barcelona, 
154 p. Published online: https://ddd.uab. cat/record/204096.

Dercourt, J., Ricou, L.E., Vrielynck, B., 1993. Atlas Tethys Palaeoenvironmental Maps, 1-307, 14 maps, 1 pl., (Gauthier-Villars) Paris.

Dieni, L, Massari, F., Moullade, M. (1963): Sur quelques Orbitolinidae des calcaires à facies "urgonien" du Crétacé inférieur des environs d'Orosei (Sardaigne). Bolletino della. Società Paleontologica Italiana 2(2): 3-8.

Granier, B., Clavel, B., Moullade, M., Busnardo, R., Charollais, J., Tronchetti, G., Desjacques, P., 2013. L'Estellon (Baronnies, France), a "Rosetta Stone" for the Urgonian biostratigraphy. Carnets de Géologie (Notebooks on Geology), Article 2013/04 (CG2013_A04).

Hottinger, L., 2006. Illustrated glossary of terms used in foraminiferal research. Carnets de Géologie / Notebooks on Geology, Memoir 2006/02 (CG2006_M02).

Kaminski, M.A., 2004. The year 2000 classification of the agglutinated foraminifera. In: Bubík, M., Kaminski, M.A. (eds). Proceedings of the Sixth International Workshop on Agglutinated Foraminifera. Grzybowski Foundation Special Publication, 8: 237-255.

Martin, K., 1890. Untersuchungen über den Bau von Orbitolina (Patellina auct.) von Borneo. Sammlungen des Geologischen Reichs-Museums in Leiden, ser. 1, 4: 209-231.

Orbigny, A., d', 1826. Tableau méthodique de la classe des Céphalopodes. Annales des Sciences Naturelles, 7: 245-314.

Pawlowski, J., Holzmann, M., Tyszka, J., 2013. New supraordinal classification of Foraminifera: Molecules meet morphology. Marine Micropaleontology, 100: $1-10$.
Peybernès, B., 1982. Les Orbitolinides Crétacés d'Afrique: Essai de Synthèse. Cahiers de Micropaléontologie, 2: 13-27.

Peybernès, B., Delmas, J., 1981. Description de Paracoskinolina prestati nov. sp., Orbitolinidé nouveau du Crétacé Moyen de la République de Somalie. Bulletin de la Société d'histoire naturelle de Toulouse, 154: 8086.

Prestat, B., 1977. Marqueurs micropaléontologiques du Jurassique et du Crétacé de Somalie centrale. Ann. Mines Géol. (Actes VI Coll. Africain Micropaléontol. Tunis 1974), 28: 273-309.

Russo, A., Bosellini, F.R., Mohamed, C.M., Yusuf, S.M., 1991. Paleoenvironmnetal analysis and cyclicity of the Mustahil Formation (Cretaceous of Central Somalia). Rivista Italiana di Paleontologia e Stratigrafia, 96 (4): 487-500.

Saint-Marc, P., 1974. Étude stratigraphique et micropaléontologique de l'Albien, du Cénomanien et du Turonien du Liban. Notes et Mémoires sur le MoyenOrient, 13: 1-342.

Schmitt, K., Heimhofer, U., Frijia, G., Di Lucia, M., Huck, S., 2019, in press. Deciphering the fragmentary nature of Cretaceous shallow-water limestone archives: A case study from the subtropical Apennine carbonate platform. Newsletters of Stratigraphy.

Schroeder, R., 1962. Orbitolinen des Cenomans Südwesteuropas. Paläontologische Zeitschrift, 36(34): 171-202.

Schroeder, R., 1985. Genre Simplorbitolina Ciry \& Rat, 1953. In: Schroeder, R., Neumann, M., (coords.). Les Grands Foraminifères du Crétacé Moyen de la région Méditerranénne. Géobios mémoire special, 7: 46-50. 